\title{
A Brief Overview on Dissolution Testing of Vitamins, Minerals, and Nutritional Supplements
}

$\mathrm{n}$ open conference on Vitamins, Minerals, and Nutritional Supplements was sponsored by the United States Pharmacopeial Conven1 tion (USP) in Scottsdale, Arizona in June 1991[1]. The purpose of this conference was to explore the possibility of outlining standards for quality and performance of nutritional supplements.

There is a wide variation between the type of standards necessary for drugs and the type of standards necessary for nutritional supplements. For example, there is a strong dose/response relationship in drugs that is non-existent with nutritional ingredients. Evidence has even been submitted where, in some cases, there is an inverse relation-

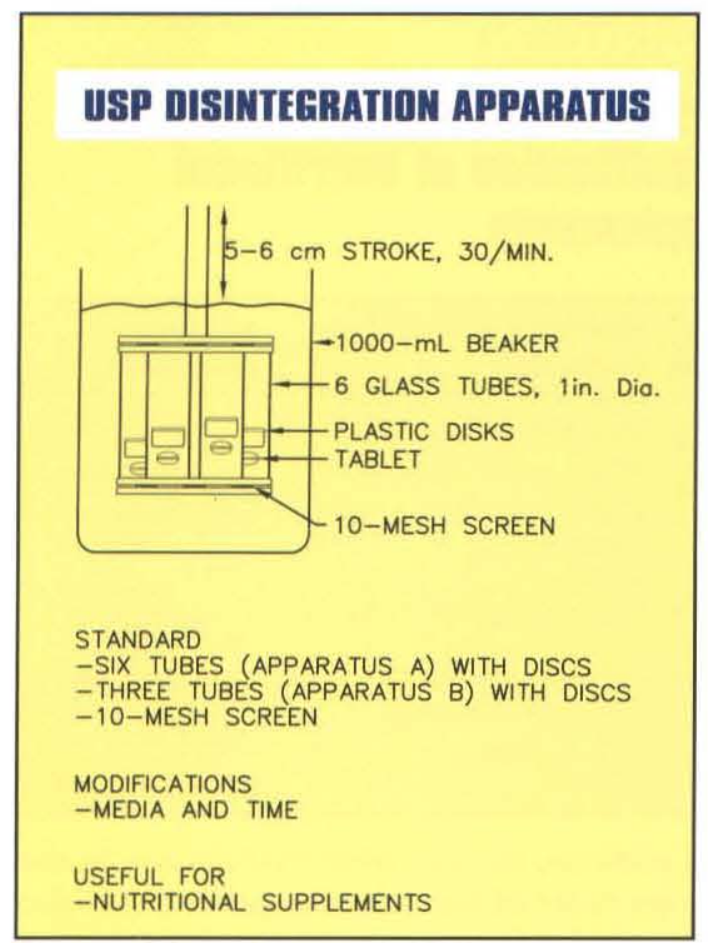

Figure 1: Schematic Diagram of USP Disintegration Apparatus $A$ \& $B$. ship between dissolution time and biological availability with some forms of nutritional supplements.

Therefore, the following new test concepts were introduced at this conference. On the assumption that little or no absorption would take place without a breakdown of the solid dosage form, an initial test using USP Disintegration Apparatus "A" (figure 1) was required. The apparatus was expanded into a larger size, Apparatus "B" (figure 1), to accommodate tablets greater than or equal to $18 \mathrm{~mm}$ long. For dissolution analysis, the concept of an index component was introduced. The index component refers to one vitamin or mineral of a multiple vitamin or miner- al formulation that is selected for assay to determine the dissolution time.

\section{March 1993}

Standards established in Supplement 8 to USP XXII / NF XVII[2] required initial disintegration testing on nutritional supplements. If the product failed to meet the disintegration criteria, dissolution testing would be required on the product. The disintegration test was performed using USP Disintegration Apparatus A for dosage forms under $18 \mathrm{~mm}$ and Apparatus B for dosage forms greater than or equal to $18 \mathrm{~mm}$ long. Refer to Table 1 for the disintegration testing requirements established for each type of dosage form.

\section{Table 1 \\ Disintegration Requirements for Nutritional supplement Dosage Forms}

\begin{tabular}{|c|c|c|}
\hline DOSAGE FORM & $\begin{array}{c}\text { DISINTEGRATION } \\
\text { MEDIA }\end{array}$ & TESTIMG TIME \\
\hline $\begin{array}{l}\text { Uncoated and } \\
\text { Film-coated tablets }\end{array}$ & water & 30 minutes \\
\hline Coated tablets & water & 45 minutes $^{*}$ \\
\hline $\begin{array}{c}\text { Hard or Soft } \\
\text { Gelatin Capsules }\end{array}$ & $0.05 \mathrm{M}$ Acetate Buffer & 45 minutes \\
\hline \multicolumn{3}{|c|}{ "Soak in water for 5 minutes prior to testing } \\
\hline
\end{tabular}

Six samples are tested initially. At the end of the specified testing time, the apparatus is examined for the presence of any palpable mass indicating incomplete disintegration. If one or two of the initial six dosage forms fail to disintegrate completely, twelve more samples are tested. Of the 18 samples, at least 16 samples must disintegrate completely. If the sample fails to meet these disintegration criteria, dissolution testing is performed on six additional samples.

The dissolution testing of nutritional supplements is performed in $0.1 \mathrm{~N} \mathrm{HCl}$ 


\section{Dissolution Testing....continued}

media. USP Dissolution Apparatus 1 (rotating basket) at 100 RPM is specified for testing capsules. USP Dissolution Apparatus 2 (paddle) at 75 RPM is specified for testing tablets. Compliance to the dissolution specifications established for nutritional supplements is determined by measuring the dissolution of one component selected as the index vitamin or mineral. The following criteria were outlined in Supplement 8 to USP XXII/NF XVII[2] for the selection of the index component.

\section{Index Vitamins and Minerals}

\section{From the list below, choose the first vitamin/mineral present in the dosage form.}

\begin{abstract}
Water-solubleVitamins
Capsules/Tablets,

Oil- andWater-soluble

Capsules/Tablets
\end{abstract}

Mineral
Capsules/Tablets

with Minerals,

Capsules/Tablets
1. Pyridoxine

2. Niacin

3. Thiamin

4. Riboflavin

1. Iron

2. Calcium

3. Zinc

4. Magnesium

Select one index vitamin and mineral from the above lists
At the one hour time point, aliquots are withdrawn from each of the six samples. The aliquots are combined and assayed for an average value of the index component from the six samples. The dissolution requirement is met if not less than $75 \%$ of the labeled content of the assayed index component is dissolved in one hour.

\section{danuary 1995}

Changes to the Nutritional Supplement disintegration and dissolution testing requirements were proposed in Pharmacopeial Forum, 19(6)[3]. These proposed modifications to the testing criteria for nutritional supplements were adopted by the USP and became effective on January 1, 1995, as stated in Supplement 1 to USP 23 / NF 18[4]. The new disintegration and dissolution criteria for nutritional supplements require that the preliminary disintegration requirement for water soluble vitamins and minerals be replaced with the dissolution test. A new classification of nutritional supplements and their dissolution testing requirements was outlined in Supplement 1 to USP 23/ NF 18[4] (Table 2).

\section{Table 2 \\ Classification of Nutritional Supplements}

\begin{tabular}{|c|c|c|}
\hline $\begin{array}{l}\text { USP } \\
\text { Class }\end{array}$ & $\begin{array}{l}\text { Deseription of Nutritional } \\
\text { Supplement }\end{array}$ & $\begin{array}{l}\text { Dissolution } \\
\text { Requirement }\end{array}$ \\
\hline I & Oil-soluble Vitamins & not applicable \\
\hline II & Water-soluble Vitamins & one index vitamin \\
\hline III & $\begin{array}{l}\text { Water-soluble Vitamins with } \\
\text { Minerals }\end{array}$ & $\begin{array}{l}\text { one index vitamin } \\
\text { and one index } \\
\text { element }\end{array}$ \\
\hline IV & Oil- and Water-soluble Vitamins & $\begin{array}{l}\text { One index water } \\
\text { soluble vitamin }\end{array}$ \\
\hline V & $\begin{array}{l}\text { Oil-and Water-soluble } \\
\text { Vitamins with Minerals }\end{array}$ & $\begin{array}{l}\text { One index water- } \\
\text { soluble vitamin and } \\
\text { one index element }\end{array}$ \\
\hline VI & Minerals & one index element \\
\hline
\end{tabular}

In addition, the following modification in the selection order of the index components was also incorporated. 


\section{Index Vitamins and Minerals}

\section{From the list below, choose the first vitamin/mineral present in the dosage form.}

Water-soluble vitamins

1. Riboflavin

2. Pyridoxine

3. Niacin

4. Thiamine

5. Ascorbic Acid

Minerals

1. Iron

2. Calcium

3. Zinc

4. Magnesium

According to Supplement 2 to USP 23 / NF 18[5], a dissolution test for folic acid is required when the nutritional supplements' labeling includes a health claim concerning folate deficiency and the risk of neural tube defects.

Overall, the dissolution requirements for nutritional supplements have increased dramatically with the recent changes in the USP Nutritional Supplement testing criteria. As this area of dissolution testing continues to evolve, the current USP supplements should be carefully reviewed to ascertain that the appropriate nutritional supplement testing criteria are being used.

References:

1.USP Open Conference on Vitamins, Minerals, and Nutritional Supplements, Scottsdale, Arizona, June 1991. Proceedings available from USP, 12601 Twinbrook Parkway, Rockville, MD 20852.

2. USP XXII/ NF XVII, Supplement 8, pp. 33683369, March 1993

3. Pharmacopeial Forum,19(6), pp. 6605-6607, NovDec 1993

4. USP 23 / NF 18, Supplement 1, pp. 2577-2578, Nov 1994

5. USP 23 / NF 18, Supplement 2, pp. 2833-2834, March 1995 